\title{
THE EFECT OF PROBIOTIC LACTOBACILLI AND ALGINITE ON THE CELLULAR IMMUNE RESPONSE IN SALMONELLA INFECTED MICE
}

\author{
Hlubeňová, K., Mudroňová, D., Nemcová, R. \\ Gancarčíková, S., Mad’ar, M., Sciranková, L. \\ Department of Microbiology and Immunology \\ University of Veterinary Medicine and Pharmacy, Komenského 73, 04181 Košice \\ Slovakia \\ dagmar.mudronova@uvlf.sk
}

\section{ABSTRACT}

Alginite is organic matter rich in humic substances and commonly found in nature, but despite that, the knowledge of its biological effects is limited. In our study we focused on monitoring the effects of alginite alone, as well as its effect as a carrier of probiotic lactobacilli on the cellular immune response in SPF mice after infection with Salmonella Typhimurium. Sixty six conventional SPF female mice of the Balb/c line were divided into 4 groups: 1. infection free negative control (NK) supplied neither alginite nor probiotic lactobacilli in the feed; 2 . infection free alginite control (Alg) supplied feed with $10 \%$ alginite; infected control supplied alginite in the feed but no lactobacilli; 3. infectious control (Alg + Sal) - animals infected with salmonella and supplied $10 \%$ alginite in the feed but no lactobacilli; and 4. probiotic group $(\mathrm{Lab}+\mathrm{Alg}+\mathrm{Sal})-$ animals infected with salmonella and administered $10 \%$ alginite and Lactobacillus reuteri 2/6 in the feed. On day 21 of the experiments, the mice were bled and their mesenteric lymph nodes were taken after their death. The peripheral blood of the mice was analysed for the activity of phagocytes and the percentage of selected lymphocyte subpopulations was determined in the mesenteric lymph nodes and blood. The significantly highest phagocytic activity (FA) was noted in the infected group with alginite $(\mathrm{Alg}+\mathrm{Sal})$. The FA was significantly increased in groups $\mathrm{Alg}$ and $\mathrm{Lab}+\mathrm{Alg}+\mathrm{Sal}$ in comparison with the NK group. The highest engulfing ability of phagocytes (phagocytic index) was observed in the $\mathrm{Lab}+\mathrm{Alg}+\mathrm{Sal}$ group in comparison with other groups, but also in Alg group in comparison with NK. In the $\mathrm{Lab}+\mathrm{Alg}+\mathrm{Sal}$ group, we observed a significantly higher percentage of B-lymphocytes, $\mathrm{CD}^{+} \mathrm{CD8}^{+}$and natural killer $\mathrm{T}$ cells (NKT), but more significant impact on the numbers of subpopulations of lymphocytes was observed in the mesenteric lymph nodes, with the significantly highest proportions of $\mathrm{CD}^{+} \mathrm{CD8}^{+}$lymphocytes and NK and NKT cells. Our results indicated immunomodulatory properties of alginite and $L$. reuteri $2 / 6$ in salmonella infected mice, especially at the level of the innate immune system components. This activation of phagocytosis and NK cells can be used in the treatment of various infections.

Key words: alginite; immune cells; immunomodulation; $L$. reuteri; mice 


\section{INTRODUCTION}

The optimum composition of intestinal microflora is important for the correct development and function of the immune system and contributes to the sustainment of good health. Proportions of intestinal bacteria are significantly affected by the lifestyle and eating habits of the population and that has changed in many ways in the recent period. Disturbances of the natural microflora have resulted in a number of health disorders. This increased interest in probiotics is due to their capability of restoring physiological microflora, ensuring the proper function of the intestine and strengthening of the immune system. It is highly probable that in the future probiotics could help to decrease the risk of serious diseases and make their prevention and treatment more effective [9].

Alginite is a sedimentary laminated rock occurring in oil shales that originated from biomass of fossil algae during several millions of years in volcanic craters [7]. Abundant deposits of alginite are located in Slovakia, close to the village Pinciná in Lučenec basin, or in Hungary in the village Pula, where it was discovered for the first time [4]. Alginite is rich in amorphous organic matter and well preserved cells of green algae Botryococcus braunii [2]. Besides organic substances, alginite contains many macro-elements, e.g. P, K, Ca, Mg, and also a number of trace elements. The content of heavy metals in alginite (As, $\mathrm{Cd}, \mathrm{Pb}$, $\mathrm{Ag}, \mathrm{Cr}, \mathrm{Se}$ ) does not exceed toxicity limits [8]. Owing to its enormous specific surface (300 to $650 \mathrm{~m}^{2} \cdot \mathrm{g}^{-1}$ ), alginite exhibits high water retention capacity (approximately $110 \%$ ). With regard to its $\mathrm{pH}$ values, alginite belongs among neutral substances with relatively high proportion of humus. Humins are a class of organic substances insoluble in water, currently used in human and veterinary medicine, particularly due to their antiviral, antibacterial, detoxification and anti-carcinogenic properties.

Owing to the high specific surfac e of alginate, it can be used as a carrier of probiotic lactobacilli and serve, at the same time, as an important source of biogenic substances with immunomodulation properties.

The aim of this study was to investigate the influence of the administration of probiotic strain Lactobacillus reuteri and alginite on cellular immune response of SPF mice.

\section{MATERIALS AND METHODS}

\section{Experimental design and animals}

The experiments were carried out within the study: "The influence of probiotic strain stabilised on fossil carrier on the intestinal micro-environment of conventional SPF mice infected with Salmonella Typhimurium", which was approved by the State Veterinary and Food Administration of SR under No. 1177/14-221.

Sixty six conventional female mice of Balb/c line (Velaz s.r.o., Prague, Czechia) were kept in rearing boxes,

Table1. Experimental groups and experimental schedule

\begin{tabular}{|c|c|c|c|}
\hline Group & $\begin{array}{l}\text { Alginite } \\
\text { (Day 0-21) }\end{array}$ & $\begin{array}{l}\text { L. reuteri } 2 / 6 \\
\text { (Day } 0-21)\end{array}$ & $\begin{array}{c}\text { Infection with } \\
\text { Salmonella Typhimurium } \\
\text { (Day 7) }\end{array}$ \\
\hline $\begin{array}{l}\text { NK } \\
\text { (negative control) } \\
(n=16)\end{array}$ & None & None & $\begin{array}{l}\text { placebo = administration of uncontaminated } \mathrm{BHI} \\
\text { broth on day } 7 \text { after on set of administration } \\
\text { of additives per os at a dose of } 0.1 \mathrm{ml} \text { per mouse }\end{array}$ \\
\hline $\begin{array}{l}\text { Alg } \\
(n=16)\end{array}$ & $\begin{array}{l}10 \% \text { addition to feed } \\
\text { throughout the experiment }\end{array}$ & None & $\begin{array}{l}\text { placebo = administration of uncontaminated } \mathrm{BHI} \\
\text { broth on day } 7 \text { after the on set of administration } \\
\text { of additives per os at a dose of } 0.1 \mathrm{ml} \text { per mouse }\end{array}$ \\
\hline $\begin{array}{l}\text { Alg+Sal } \\
(n=17)\end{array}$ & $\begin{array}{l}10 \% \text { addition to feed } \\
\text { throughout the experiment }\end{array}$ & None & $\begin{array}{l}10^{8} \mathrm{CFU} \cdot \mathrm{ml}^{-1} \mathrm{~S} \text {. Typhimurium in } \mathrm{BHI} \text { broth per os } \\
\text { at a dose of } 0.1 \mathrm{ml} \text { per mouse on day } 7 \text { after the } \\
\text { on set of administration of additives }\end{array}$ \\
\hline $\begin{array}{l}\text { Lab+Alg+Sal } \\
(\mathrm{n}=17)\end{array}$ & $\begin{array}{l}10 \% \text { addition to feed } \\
\text { throughout the experiment }\end{array}$ & $\begin{array}{l}10^{8} \mathrm{CFU} \cdot \mathrm{g}^{-1} \\
\text { Stabilised on alginate } \\
\text { throughout the experiment }\end{array}$ & $\begin{array}{l}10^{8} \mathrm{CFU} \cdot \mathrm{ml}^{-1} \mathrm{~S} \text {. Typhimurium in } \mathrm{BHI} \text { broth per os } \\
\text { at a dose of } 0.1 \mathrm{ml} \text { per mouse on day } 7 \text { after onset } \\
\text { of administration of additives }\end{array}$ \\
\hline
\end{tabular}


6-7 mice per box, were fed ad libitum a complete mixed feed for mice Altromin 1311 (Altromin International, Germany) and they had unrestricted access to water. The experimental schedule is presented in Table 1.

\section{Characteristics of bacterial strains and their cultivation}

In the experiment we tested probiotic, exopolysaccharides-producing porcine strain Lactobacillus reuteri 2/6. This strain was isolated from the faeces of a clinically healthy pig at the Institute of microbiology and gnotobiology of the University of Veterinary Medicine and Pharmacy in Košice. For accurate identification of this lactobacillus in the organism of mice, we used spontaneous rifampicinresistant isolates of this strain obtained by cultivation on MRS (deMan, Rogosa and Sharpe) agar (Becton Dickinson and Company Microbiology systems, USA), containing $30 \mu \mathrm{g} \cdot \mathrm{ml}^{-1}$ rifampicin (Sigma Chemical Co., UK). Lactobacilli were cultivated anaerobically on MRS agar for 48 hours or in MRS broth at $37^{\circ} \mathrm{C}$ for 24 hours. For the preparation of the inoculum, we used night (18 h) cultures from MRS broth that was inoculated onto alginite previously saturated with $40 \%$ lactose. The solid state fermentation took place at $37^{\circ} \mathrm{C}$ for 24 hours. Alginite was then lyophilised and lactobacilli counts were determined, which reached $10^{8} \mathrm{CFU}^{-1}{ }^{-1}$.

The experimental mice from groups $\mathrm{Alg}+\mathrm{Sal}$ and $\mathrm{Lab}+\mathrm{Alg}+$ Sal were infected with Salmonella Typhimurium CCM 7205, obtained from Masarykova University in Brno, Czechia. They were cultivated at $37^{\circ} \mathrm{C}$ for 24 hours on Brilliant Green agar (BGA, Laboratories Conda, Spain). Inoculum for infecting the mice was prepared in $\mathrm{BHI}$ broth (BHI, Merck, Germany) at $37^{\circ} \mathrm{C}$ from the night culture.

\section{Collection of samples and preparation of lymphocytes}

On day 14 post infection (day 21 of the experiment), samples of the peripheral blood were collected from the sinus orbitalis of mice into heparin containing tubes. Eight mice from each group were used for immunological analysis. Mesenteric lymphatic nodes (MLN) were collected from these mice immediately after death $\left(86 \mathrm{mg} \cdot \mathrm{kg}^{-1}\right.$ body weight, sodium pentobarbital, cervical dislocation). They were placed into an ice-cold Hank's solution (137 mM NaCl; $5 \mathrm{mM} \mathrm{KCl} ; 1.1 \mathrm{mM} \mathrm{Na} \mathrm{HPO}_{4} .2 \mathrm{H}_{2} \mathrm{O} ; 0.4 \mathrm{mM} \mathrm{KH} \mathrm{PO}_{4}$; 5 mM D-glucose; $4 \mathrm{mM} \mathrm{NaHCO}_{3} ; 10$ mM HEPES; $\mathrm{pH} 7.1-$ 7.3). Lymphocytes were isolated from MLN by compressing the MLN between 2 sterile slides. The obtained suspension was washed in cold PBS (MP Biomedicals, France) and centrifuged for $5 \mathrm{~min}$ at $600 \mathrm{~g}$. The number of lymphocytes was adjusted to $10^{6} .50 \mu \mathrm{l}^{-1}$.

\section{Phenotyping and phagocytic activity of immune cells}

The cells were identified by means of direct labelling with monoclonal antibodies conjugated with fluorochromes (eBioscience, USA) in the following combinations: CD4/CD8a/CD49b and CD3/B220. Specification of the antibodies used is presented in Table 2.

The cells were labelled as follows: $50 \mu$ of blood or cell suspension from MLN were incubated with monoclonal antibodies in tubes for $15 \mathrm{~min}$ in the dark at laboratory temperature. Then $500 \mu \mathrm{l}$ of lysing solution (BD FACS Lysing Solution, BD Biosciences, USA) was added to the tubes with the blood, the tubes were again incubated for $15 \mathrm{~min}$ in the dark at laboratory temperature and were washed twice with $1 \mathrm{ml}$ PBS (centrifugation for $5 \mathrm{~min}$ at $600 \mathrm{~g}$ ). Finally, $100 \mu \mathrm{l}$ PBS was added to each tube and cytometric analysis was performed immediately employing a flow cytometer BD FACSCantoTM (Becton Dickinson Biosciences, USA). The position of lymphocytes was displayed on a basic dot plot FSC (forward-scattered light) against SSC (side-scattered light). Proportions of individual subpopula-

Table 2. Specification of anti-murine monoclonal antibodies used in the experiments

\begin{tabular}{|c|c|c|c|c|c|}
\hline Type & Fluorochrome & Clone & Isotype & Concentration & Volume \\
\hline anti-CD4 & FITC & GK 1.5 & $\lg G 2 b, k$ & $0.5 \mathrm{mg} \cdot \mathrm{ml}^{-1}$ & $4 \mu \mathrm{l}$ \\
\hline anti-CD8a & R-PE & $53-6.7$ & $\lg G 2 a, k$ & $0.2 \mathrm{mg} \mathrm{ml}^{-1}$ & $2 \mu l$ \\
\hline anti-CD49b & APC & DX5 & $\lg M, k$ & $0.2 \mathrm{mg} \mathrm{ml}^{-1}$ & $1 \mu l$ \\
\hline anti-CD3 & PerCP-eFluor710 & $17 \mathrm{~A} 2$ & $\lg G 2 b, k$ & $0.2 \mathrm{mg} \mathrm{ml}^{-1}$ & $2 \mu l$ \\
\hline anti-B220 & PE-Cyanine7 & RA3-6B2 & $\lg G 2 a, k$ & $0.2 \mathrm{mg} \cdot \mathrm{ml}^{-1}$ & $2 \mu \mathrm{l}$ \\
\hline
\end{tabular}


tions were determined by means of dot plots for relevant fluorescences (CD4 against CD8; CD8 against CD49b; CD3 against B220) and expressed as per cent proportions of all lymphocytes. The obtained data were analyzed using BD FACS DivaTM software.

The phagocytic activity was det-6B2ermined using the above mentioned flow cytometer and commercial kit Phagotest $^{\oplus}$ (Orpegen Pharma, Germany).

\section{Statistical analysis}

Statistical analysis was performed by the one-way analysis of variance (one-way ANOVA) and Tukey test, using software GraphPad Prism. The level of significance was set to $\mathrm{P}<0.05$.

\section{RESULTS AND DISCUSSION}

In the experimental groups $\mathrm{Alg}, \mathrm{Alg}+\mathrm{Sal}$, and $\mathrm{Lab}+\mathrm{Alg}+\mathrm{Sal}$, we observed a significant increase in phagocytic activity and engulfing ability of phagocytes (phagocytic index). The highest phagocytic activity was recorded in group Alg + Sal and lower in the group with simultaneous administration of lactobacilli $(\mathrm{Lab}+\mathrm{Alg}+\mathrm{Sal})$, which may be related to better clinical status of mice in this group (Fig. 1a). The highest engulfing ability of phagocytes was observed in group $\mathrm{Lab}+\mathrm{Alg}+\mathrm{Sal}$ (Fig. 1b). The induction effect of lactobacilli on phagocytic activity was reported in the study by Perdigón et al. [5] in which per os adminis- tration of $L$. casei significantly increased phagocytic activity of macrophages in mice. The immunostimulating effect of humic acids was also confirmed by $\mathrm{Habibian}$ et al. [3], who observed dose-dependent potentiation of phagocytic activity of mononuclear cells in rats.

The significantly highest percentage proportion of CD4+ lymphocytes in the peripheral blood was observed in group $\mathrm{Alg}+\mathrm{Sal}$, and alginate itself significantly decreased this proportion in healthy animals in comparison with group NK (Fig. 2a). In group $\mathrm{Lab}+\mathrm{Alg}+\mathrm{Sal}$ we recorded the highest number of both $\mathrm{CD} 4^{+} \mathrm{CD} 8^{+}$lymphocytes (Fig. 2b) and NKT (CD49b $\left.{ }^{+} \mathrm{CD}^{+}\right)$cells (Fig. 2c), which contradicts the results of Gill et al. [1] who failed to observe any noticeable effect of the administration of probiotics on subpopulations of lymphocytes in mice. However, subpopulation of $\mathrm{NK}$ cells $\left(\mathrm{CD} 4 \mathrm{~b}^{+} \mathrm{CD}^{-}\right)$in lactobacilli and alginite infected groups in our study was significantly lower in comparison with alginite control (Fig. 2d).

In mesenteric lymph nodes we observed a significant stimulation of cellular response in group $\mathrm{Lab}+\mathrm{Alg}+\mathrm{Sal}$, which showed the significantly highest proportion of double-positive $\mathrm{CD}^{+} \mathrm{CD}^{+}$lymphocytes (Fig. 3a), NK cells (Fig. 3b) and NKT cells (Fig. 3c). The proportion of $\mathrm{CD}^{+}$ lymphocytes was significantly increased in both infected groups (Fig. 3d). The positive influence of lactobacilli on local immune response was observed also in the study by PerdIgón et al. [6], who also recorded an increase in $\mathrm{CD} 4{ }^{+}$cells in the small intestine of mice after the administration of L. casei and L. plantarum. a)

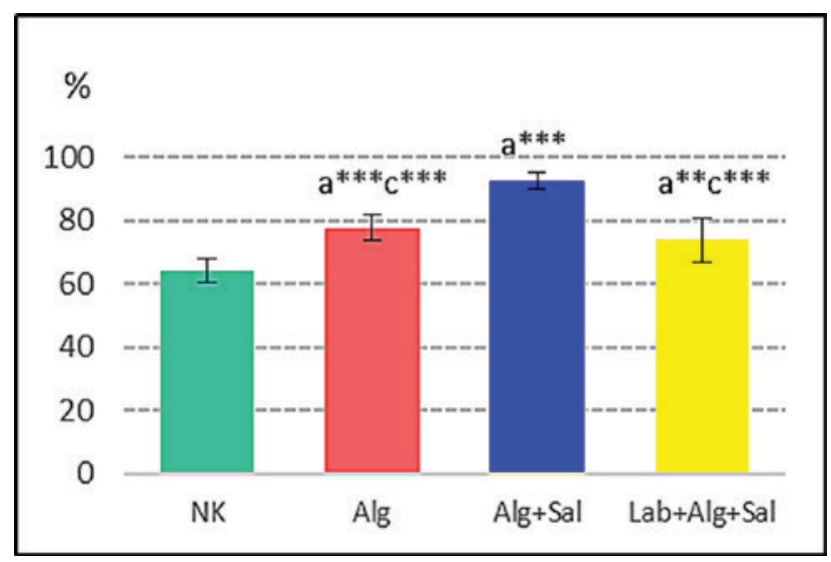

b)

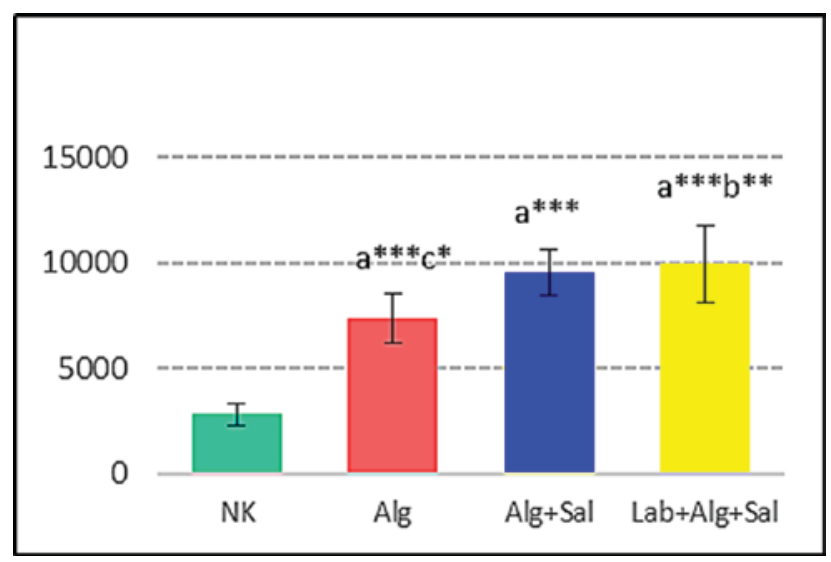

Fig. 1. The influence of the administration of probiotic strain L. reuteri and alginite on: a) Phagocytic activity and b) Phagocytic index in mice infected with Salmonella Typhimurium

a - significant difference compared to NK; b - significant difference compared to Alg; $\mathrm{c}-$ significant difference compared to Alg+Sal; ${ }^{\star}-\mathrm{P}<0.05 ;^{* *}-\mathrm{P}<0.01 ;^{* * *}-\mathrm{P}<0.001$ 
a)

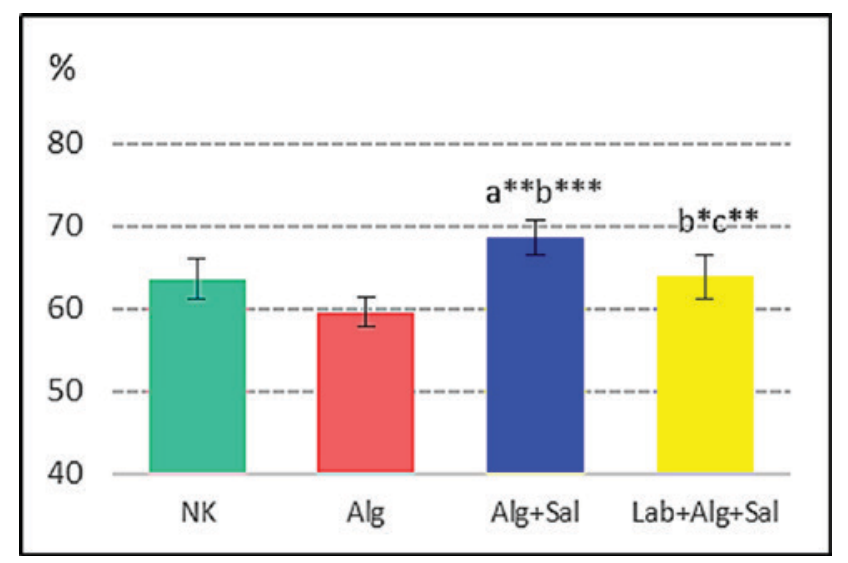

c)

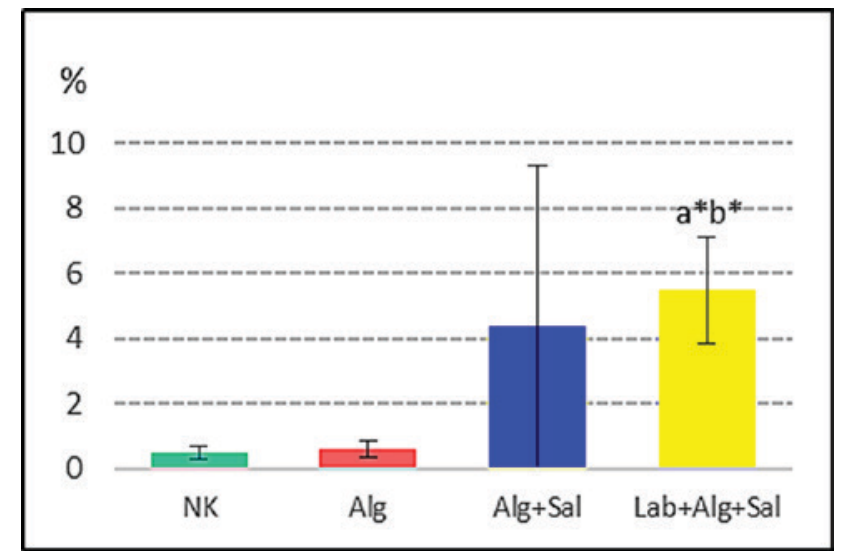

b)

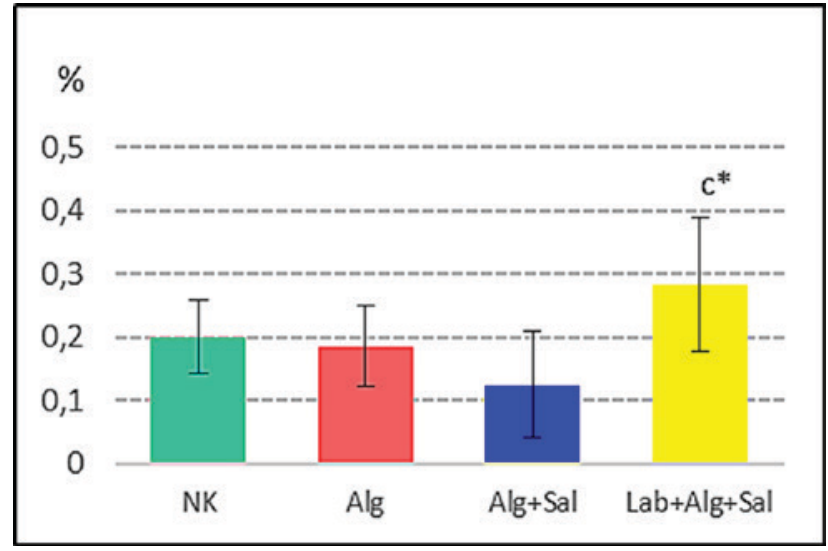

d)

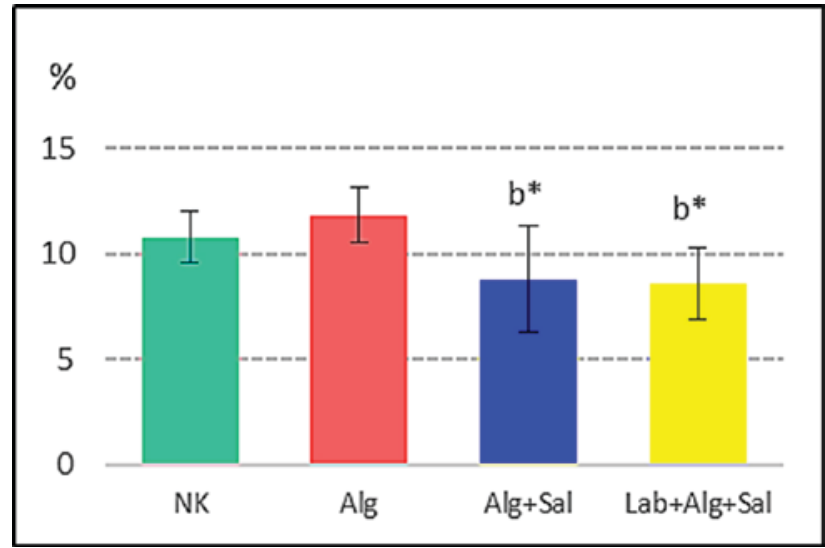

Fig. 2. The influence of the administration of probiotic strain L. reuteri and alginite on proportions of the following lymphocytes in peripheral blood of mice infected with $S$. Typhimurium: a) $\mathrm{CD4}^{+}$; b) $\mathrm{CD}^{+} \mathrm{CD8}^{+}$; c) $\mathrm{CD}_{91} \mathrm{~b}^{+} \mathrm{CD8}^{+}$; d) $\mathrm{CD} \mathrm{Cb}^{+} \mathrm{CD8}^{-}$

a - significant difference compared to NK; b - significant difference compared to Alg; $\mathrm{c}$ - significant difference compared to Alg+Sal; ${ }^{*}-\mathrm{P}<0.05 ;{ }^{* *}-\mathrm{P}<0.01 ;{ }^{* *}-\mathrm{P}<0.001$

\section{CONCLUSIONS}

Our experiment indicated an immunomodulation potential of lactobacilli and humic substances found in alginite. In the group infected with $S$. Typhimurium, the cellular immune response was significantly stimulated by the administration of L. reuteri and alginate, particularly at the local level, in mesenteric lymph nodes of mice by activation of $\mathrm{CD}^{+} \mathrm{CD}^{+}$lymphocytes, NK and NKT cells, and at the level of the innate immune system component by activation of phagocytosis.

\section{ACKNOWLEDGEMENT}

This study was supported by the Slovak Research and De- velopment Agency on the basis of the Agreement No. APVV0199-11 and by the structural project EU INFEKTZOON (ITMS 26220120002).

\section{REFERENCES}

1. Gill, H.S., Rutherfurd, K. J., Prasad, J., Gopal, P. K., 2000: Enhancement of natural and acquired immunity by Lactobacillus rhamnosus (HN001), Lactobacillus acidophilus (HN017) and Bifidobacterium lactis (HN019). British Journal of Nutrition, 83, 167-176.

2. Gömöryová, E., Vass, D., Pichler, V., Gömöry, D., 2009: Effect of alginite amendment on microbial activity and soil water content in forest soils. Biologia, 64, 585-588. 
a)

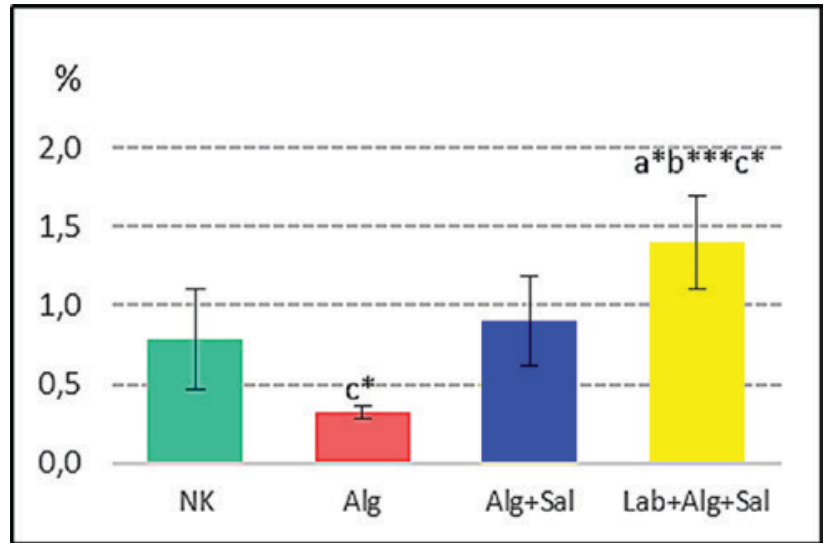

c)

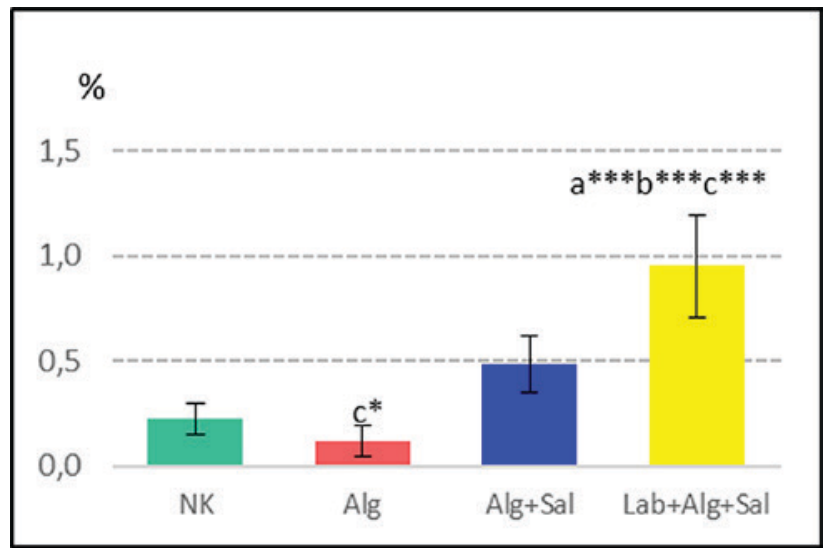

b)

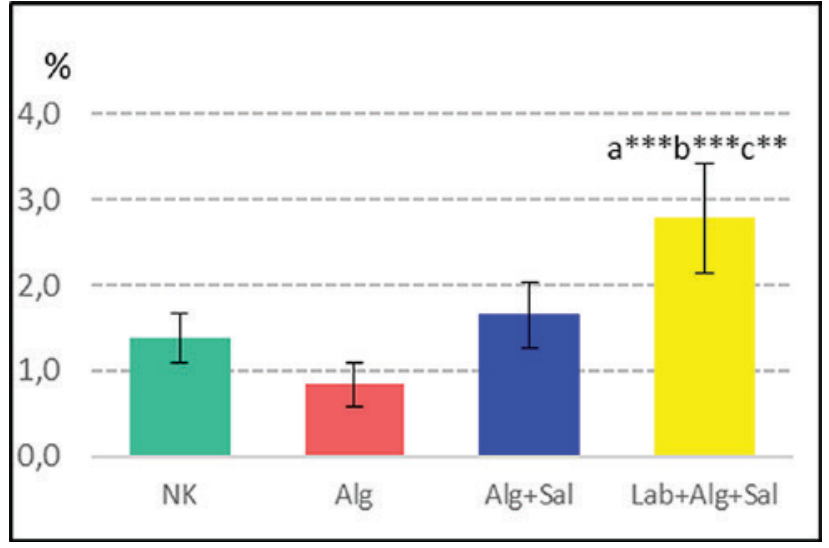

d)

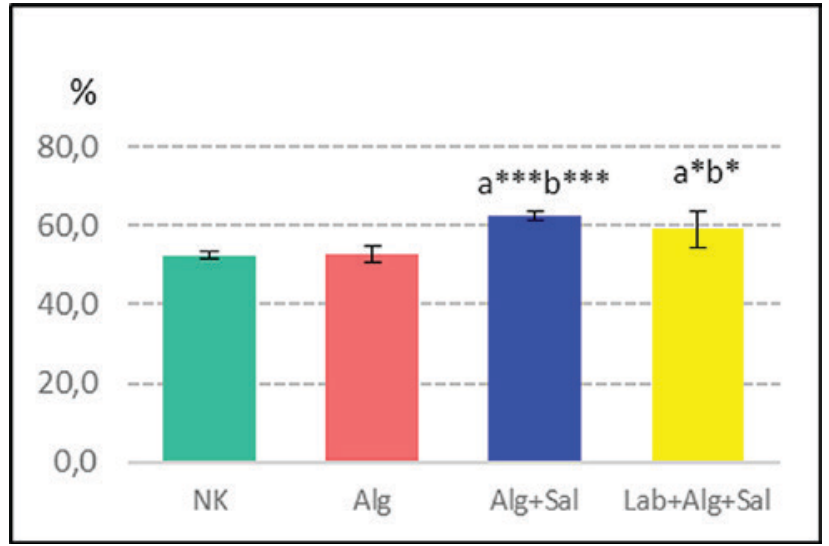

Fig. 3. The influence of the administration of probiotic strain L. reuteri and alginite on proportion of the following lymphocytes

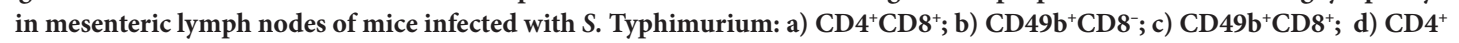
a - significant difference compared to NK; b - significant difference compared to Alg; $\mathrm{c}$ - significant difference compared to Alg + Sal; ${ }^{*}-\mathrm{P}<0.05 ;{ }^{* *}-\mathrm{P}<0.01 ; * * *-\mathrm{P}<0.001$

3. Habibian, R., Morshedi, A., Delirezh, N., 2010: Effect of humic acid on humoral immune response and phagocytosis. Global Veterinaria, 4, 135-139.

4. Kulich, J., Valko, J., Obernauer, D., 2001: Perspective of exploitation of alginite in plant nutrition. Journal of Central European Agriculture, 2, 199-206.

5. Perdigón, G., de Macias, M.E., Alvarez, S., Oliver, G., de Ruiz Holgado, A. A., 1986: Effect of perorally administered lactobacilli on macrophage activation in mice. Infect. Immun., $53,404-410$.
6. Perdigón, G., Vintiñi, E., Alvarez, S., Medina, M., Medici, M., 1999: Study of the possible mechanisms involved in the mucosal immune system activation by lactic acid bacteria. J. Dairy Sci., 82, 1108-1114.

7. Szabó, L.P., 2004: Characterization of alginite humic acid content. Desalination, 163, 85-91.

8. Vass, D., Elečko, M., Konečný, V., 1997: Alginite, a raw material for environmental control. Geology Today, 13, 149-153.

9. Yan, F., Polk, D.B., 2011: Probiotics and immune health. Curr. Opin. Gastroenterol., 27, 496-501.

Received May 17, 2017

Accepted June 6, 2017 